\title{
The fishes of Lake Kununurra, a highly regulated section of the Ord River in northern Western Australia
}

\author{
H.S. Gill' ${ }^{1}$, D.L. Morgan ${ }^{1}$, R.G. Doupé ${ }^{2}$ and A.J. Rowland ${ }^{1}$ \\ ${ }^{1}$ Centre for Fish and Fisheries Research, Murdoch University, \\ South Street, Murdoch, Western Australia 6150 \\ ${ }^{2}$ Fish Health Unit, Division of Veterinary and Biomedical Sciences, Murdoch University, \\ South Street, Murdoch, Western Australia 6150
}

\begin{abstract}
The Ord River, situated in the east Kimberley region of Western Australia, is regulated by two dams that supply irrigation water for tropical agriculture. The regulation of water in the $55 \mathrm{~km}$ span of river between these dams has resulted in this section now resembling a lacustrine rather than riverine environment that is reflected in its name, Lake Kununurra. Utilising various sampling techniques we captured/observed 4157 fish from 19 species in 13 families, whilst the presence of a further three species was confirmed by reliable sources. Nematalosa erebi, Craterocephalus stramineus and Melanotaenia australis were the three most widespread and abundant species, being encountered throughout the lake and representing $-66 \%$ of all fish recorded. Ambassis sp., Arius midgleyi, A graeffei, Glossamia aprion, Amniataba percoides, Hephaestus jenkinsi, Glossogobius giurus and Toxotes chatareus were found throughout the lake but generally at fewer sites and in smaller numbers $(\sim 30 \%$ of all fish) than the three dominant species. The remaining species Neosilurus ater, Strongylura krefftii, Leiopotherapon unicolor, Syncomistes butleri, Lates calcarifer, Mogurnda mogumda, Oxyeleotris lineolatus and Ambassis macieayi were generally found at few sites and in low numbers, and accounted for less than $4 \%$ of the overall catch. The regulation of the Ord River has apparently altered the species composition and abundances in Lake Kununurra. For example, marine/estuarine species, commonly encountered in the freshwaters of large northern Australian Rivers, are largely absent, while species such as $L$. unicolor, which is one of the most abundant species in nearby rivers and tropical Australian rivers in general, contributed to $<1 \%$ of the total catch.
\end{abstract}

\section{INTRODUCTION}

The Ord River, situated in the east Kimberley region of Western Australia, has an arid and semiarid monsoonal catchment of over $50000 \mathrm{~km}^{2}$ that extends into the western Northern Territory. The $650 \mathrm{~km}$ long river, which originates northwest of Halls Creek and drains into the Cambridge Gulf near Wyndham, has a mean annual stream flow of 3940 GL (into Lake Argyle), the second largest in Western Australia (Water and Rivers Commission 2000). The river is regulated by two dams that supply irrigation water for tropical agriculture. Completed in 1963, the Kununurra Diversion Dam was built across the Ord River and created Lake Kununurra. Approximately $55 \mathrm{~km}$ upstream of the Diversion Dam, the Ord River Dam that forms Lake Argyle, was completed in 1973.

Operation of the Kununurra Diversion Dam spillway gates, along with continual water release from the Ord River Dam, maintains relatively constant water levels in Lake Kununurra throughout the year. Thus, these dams have essentially altered the flow regime of this section of the river from lotic to lentic conditions. Such modification often results in changes in fish communities, such as a reduction in the relative abundance of species that favour faster flowing reaches of rivers along with a concomitant increase in the abundance of those species restricted to slower flowing sections. Dams also often impede species migrations within river systems (Bunn and Arthington 2002).

Constant water levels within the lake have encouraged the development of profuse riparian vegetation. The inundation of surrounding lowlands also has resulted in many fringing swamps that are characterised by rich aquatic plant growth, large woody debris and extensive stands of emergent vegetation, such as the bulrushes Typha domingensis and Eleocharis spp. (Jaensch 1993). In recognition of its significance as a dry-season refuge for waterbirds, due to the consistency in the water level of the lake and its varied habitats, Lake Kununurra is now classified under the Ramsar convention as a "wetland of international importance". 
Despite its listing as a wetland of international importance, and noting the likely effects of habitat change and large dams on the teleost fauna, no literature exists detailing the lake's fishes. Thus, the primary aim of this study was to determine the fish fauna of Lake Kununurra. The distributions and broad habitat associations of the species in the lake are also discussed.

\section{MATERIALS AND METHODS}

\section{Sample sites}

The term 'Lake Kununurra', in the present study, refers to the $55 \mathrm{~km}$-long body of water between the Lake Kununurra Diversion Dam and the Ord River
Dam, including the tributaries and associated perennial swamps and lagoons (Figure 1) (Jaensch 1993). In order to capture representatives of each species within Lake Kununurra extensive sampling was undertaken at 16 sites throughout its length in a variety of habitats (Figure 1).

\section{Sampling methods}

Sampling was conducted during day-light hours in November and December 2002. During this time the fish fauna of the sites were sampled using a variety of methods, including monofilament gill nets $(50,100,125,150$ and $200 \mathrm{~mm}$ stretched mesh), seine nets ( 5 and $15 \mathrm{~m}$ nets of $3 \mathrm{~mm}$ woven mesh), rod and line, and visual surveys (e.g., mask and

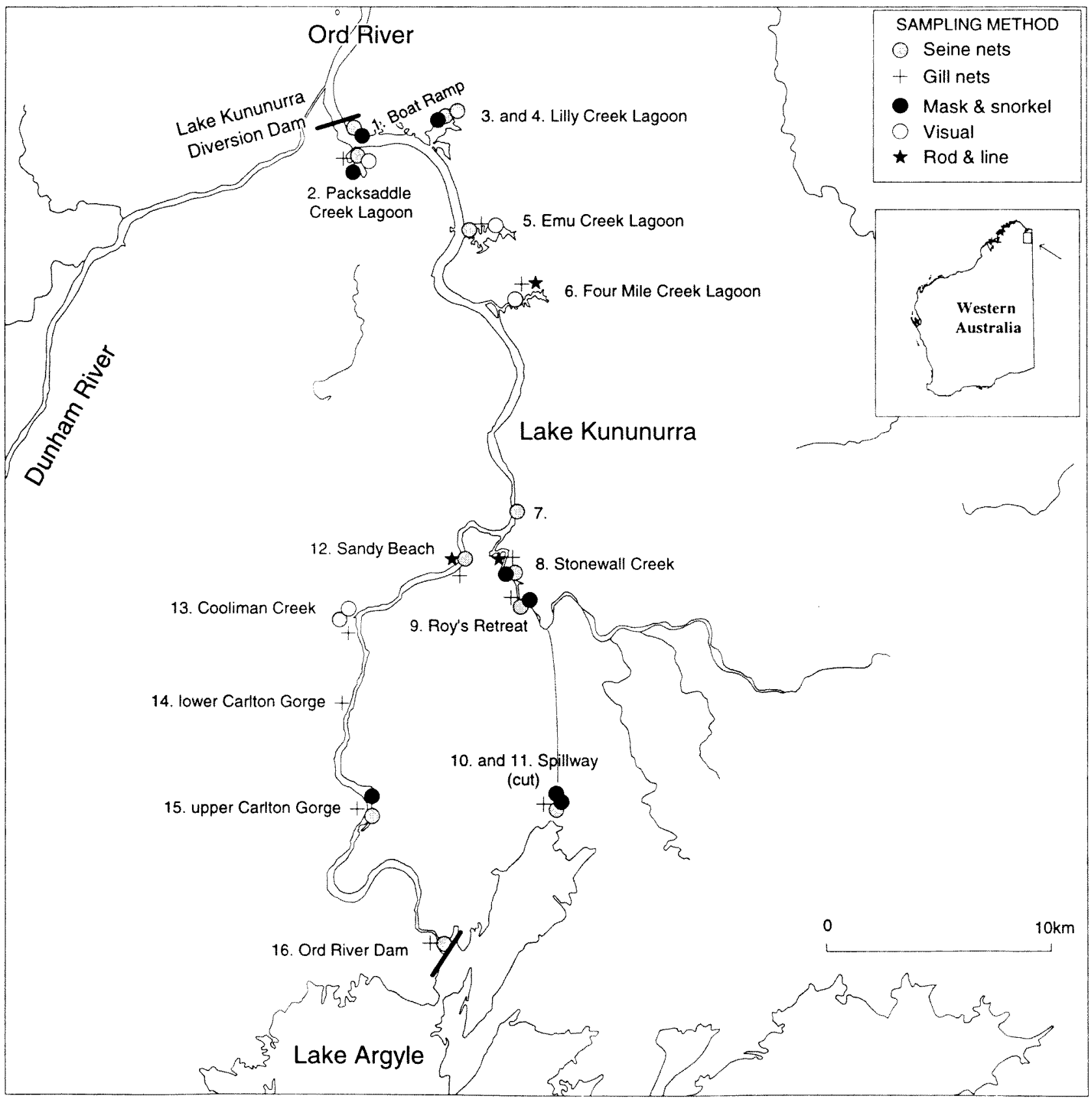

Figure 1 The sites sampled and the methods used to survey the fish fauna in Lake Kununurra. 
snorkel). On capture, fish were identified, the number of each species recorded and the majority then released. A global positioning system (GPS) was used to determine the longitude and latitude of each site, and these data were then used, in conjunction with the computer program MapInfo (MapInfo Corporation 1998), to produce a map showing their location (Figure 1).

\section{RESULTS}

A total of 4157 fish from 19 species in 13 families were captured/observed in Lake Kununurra during the present study (Table 1). Three species dominated catches at the majority of sites within the system and accounted for $66 \%$ of the total catch. Bony Bream Nematalosa erebi (Günther, 1868) accounted for $27.3 \%$ (1133) of captured fish and was recorded at 11 of the 16 sites sampled. The Strawman Craterocephalus stramineus (Whitley, 1950) and Western Rainbowfish Melanotaenia australis (Castelnau, 1875) represented $\sim 20.1 \% \quad(837$ individuals) and $-18.6 \%$ (775 individuals), respectively, and were each recorded from 12 sites (Table 1). The first of these species was most common in shallows near deep water where groups were observed feeding over sand or gravel substrates whereas the two smaller species were typically caught along the well-vegetated margins where they congregated in moderate to large schools near the surface in areas of low flow.

A further seven species were also widely distributed, and accounted for just over $30 \%$ of the total catch (Table 1). In decreasing abundance were Northwest Glassfish Ambassis sp. ( 8.5\%, 356 individuals, 6 sites), a species associated with areas of little water flow and copious growths of aquatic vegetation and was formerly referred to as Ambassis muelleri Klunzinger, 1880 , by Allen and Burgess (1990); Silver Cobbler or Shovel-nosed Catfish Arius midgleyi Kailola and Pierce, 1988 (4.8\%, 201 individuals) was captured at nine sites, from below the Ord River Dam downstream to Packsaddle Creek Lagoon; Mouth Almighty Glossamia aprion (Richardson, 1842) made up almost 5\% of the total catch and was found throughout Lake Kununurra (198 individuals, 8 sites), where it was generally associated with aquatic vegetation; Barred Grunter Amniataba percoides (Günther, 1864) was widespread and relatively common $(-3.2 \%, 134$ individuals, 11 sites), forming aggregations in the shallows over gravel, sand, or mud in fast (e.g., upper Spillway Creek) to slow flowing or still waters (e.g., Lilly Creek Lagoon); Jenkin's or Western Sooty Grunter, or colloquially Black Bream Hephaestus jenkinsi (Whitley, 1945) represented $\sim 2.8 \%$ of the total catch (117 individuals) and was captured in nine sites from Packsaddle Creek Lagoon to Carlton Gorge where it was often associated with deep water and structure in the form of submerged roots, logs, rocks or vegetation; Flathead Goby Glossogobius giurus (Hamilton, 1822) was relatively common and widespread $(-2.4 \%, 98$ individuals, 8 sites) and was most often found in the shallows on sandy bottoms; Lesser Salmon or Blue Catfish Arius graeffei Kner and Steindachner, 1867 was captured at six sites from Carlton Gorge downstream to Packsaddle Creek Lagoon $(\sim 2.3 \%, 96$ individuals) and was also common in the lower Ord River and Lake Argyle (Rowland unpublished data); Seven-spot Archerfish Toxotes chatareus (Hamilton, 1822) was relatively common and widespread throughout Lake Kununurra $(\sim 1.6 \%$, 66 individuals, 8 sites), where it was commonly observed patrolling the surface near river banks or around riparian vegetation.

The remaining seven species encountered during this study, i.e., Black Catfish Neosilurus ater (Perugia, 1894); Freshwater Longtom Strongylura krefftii (Günther, 1866); Spangled Perch Leiopotherapon unicolor (Günther, 1859); Butler's Grunter Syncomistes butleri Vari, 1978; Barramundi Lates calcarifer (Bloch, 1790); Northern Trout Gudgeon Mogurnda mogurnda (Richardson, 1844); Sleepy Cod Oxyeleotris lineolatus (Steindachner, 1867) and Macleay's Glassfish Ambassis macleayi (Castelnau, 1878), were caught in low numbers and/ or at few sites and in total contributed less than $4 \%$ to the overall catch (Table 1).

Three further species not captured during this study have been reported from Lake Kununurra; these were Freshwater Sawfish Pristis microdon Latham, 1794 (Thorburn et al. 2003), Rendahl's Catfish Porochilus rendahli (Whitley, 1928) (G. Allen and M. Allen unpublished data) and Giant Glassfish Ambassis gulliveri (Castelnau, 1878) (S. McIntosh personal communication).

\section{DISCUSSION}

The results of this study demonstrate that, although Lake Kununurra is a highly modified section of the Ord River, the number of freshwater species inhabiting the lake is comparable to those found elsewhere in the Kimberley. For example, the capture of 18 freshwater species, not including the catadromous $L$. calcarifer, during this study, in addition to reports of two other species from reliable sources, compares with 23 freshwater fish species found throughout the entire Fitzroy River (Morgan et al. 2002), 18 species from the Prince Regent River (Allen 1975), 19 from the Drysdale and Carson Rivers (Hutchins 1977), and nine from the Mitchell River (Hutchins 1981).

Of the 4157 fish caught in the present study the most abundant and commonly encountered species, Nematalosa erebi, Craterocephalus stramineus, Melanotaenia australis, Ambassis muelleri, Arius midgleyi, Glossamia aprion, Amniataba percoides, 
Table 1 The number of each fish species caught at each of the sites sampled in Lake Kununurra. NB. Site ,1 Swim Beach boat ramp; 2, Packsaddle Creek Lagoon; 3, Lilly Creek Lagoon (boat ramp); 4, Lilly Creek Lagoon; 5, Emu Creek Lagoon; 6, Four Mile Creek Lagoon; 7, main channel (opposite Stonewall Creek); 8 , Stonewall Creek (mouth); 9, Stonewall Creek (Roy's Retreat); 10, Spillway Creek (upper); 11, Spillway Creek (below spillway); 12 main channel (Sandy Beach); 13, Cooliman Creek; 14, main channel (lower Carlton Gorge); 15, main channel (upper Carlton Gorge); 16, main channel (below Ord Dam). ${ }^{*}$ Although no $N$. erebi were captured at Site 16 during the present study they were seen there on a previous trip. (See Figure 1 for site locations).

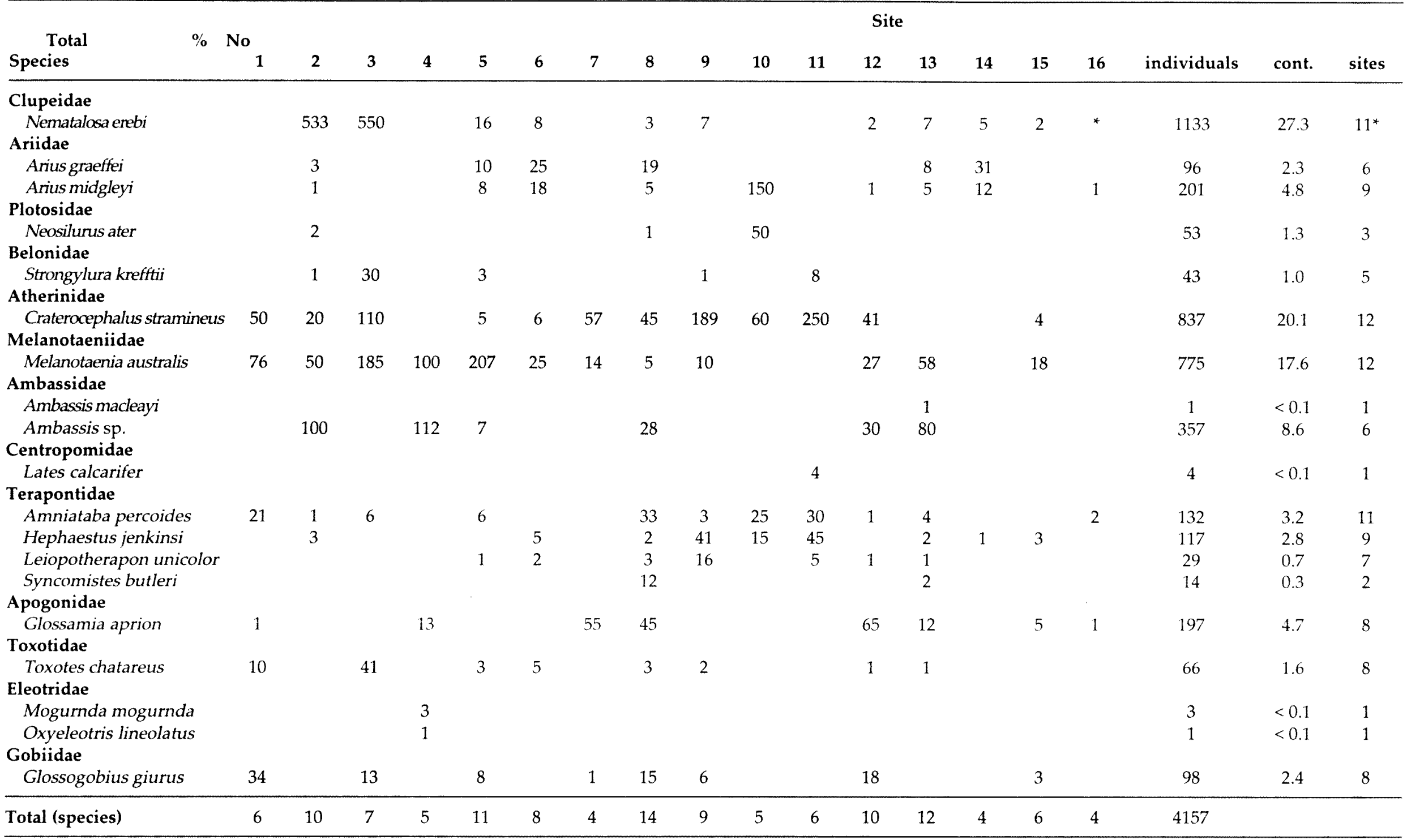


Hephaestus jenkinsi, Glossogobius giurus, Arius gracffei, Toxotes chatareus, were all recorded from the lower-most regions of the lake (Swim Beach Boat Ramp and/or Packsaddle Creek Lagoon) and, with the exception of Ambassis sp., Arius graeffei and $T$. chatare'us, were also found in the upper-most sites (i.e., upper Carlton Gorge and /or immediately below the Ord Dam). The last three species were, however, captured at Cooliman Creek and/or lower Carlton Gorge, sites that are in the upper third of the lake.

Nematalosa erebi, C. stramineus and $M$. anstralis, in addition to being widespread throughout the system, were the most numerous and frequently encountered fishes caught during this study. However, whilst $N$. erebi was often associated with the deeper main channel, the smaller species $C$. stramineus and $M$. australis were usually observed in the shallow vegetated littoral zones. The fact that much of the Lake Kununurra environment consists of the preferred habitat of $N$. erebi, i.e. still or slow flowing vegetated waterbodies with mud/sand substrate (Bishop et al. 2001) would help explain why this species is so abundant and widespread within the lake. In the case of $C$. stramineus and $M$. australis, the dense emergent and submerged littoral vegetation would provide not only a refuge for these small fish from predators, but also a rich source of terrestrial and aquatic insect prey.

The rarer species encountered in Lake Kununurra include Ambassis macleayi, Leiopotherapon unicolor, Syncomistes butleri, Mogurnda mogurnda and Oxyeleotris lineolatus. Some are genuinely rare throughout parts of their range such as $A$. macleayi (Merrick and Schmida 1984), whilst others, such as O. lineolatus, are generally cryptic species that hide amongst snags (Allen et al. 2002) and are difficult to catch, and thus are possibly under-represented in our samples. However, L. unicolor is usually one of the most numerous species encountered in freshwaters throughout the Pilbara and Kimberley (Morgan of al. 2004; Morgan and Gill 2004), yet is very rare in Lake Kununurra. A possible explanation for this observation is that in $L$. unicolor the stimulus to spawn is apparently associated with flood events (Llewellyn 1973; Beumer 1979), which, due to regulation, are minimised within the main body of Lake Kununurra. An examination of $L$. linicolor capture locations lends support to this explanation as the majority of L. minicolor were captured from sites in Stonewall and Spillway creeks, i.e. watercourses that resemble naturally flowing Kimberley streams and are subjected to flood flows during the wetseason. Such an explanation is also supported by the work of Bunn and Arthington (2002) who noted that some Australian freshwater fish species, as a result of life history strategies evolved in direct response to natural flow, are likely to suffer recruitment failure when subjected to altered flow regimes and impoundment conditions.

Although the fish fauna of the Lake Kununurra section of the Ord River is relatively rich, it is likely that it would have been even more diverse prior to damming. For example, the $20 \mathrm{~m}$ dam wall provides an insurmountable barrier to the movement of catadromous species, such as Bullshark Carcharhinus leucas (Valenciennes, 1839), Freshwater Sawfish P. microdon, Freshwater Whipray Himantura chaophrya Monkolprasit and Roberts, 1990, Tarpon Megalops cyprinoides (Broussonet, 1782), Barramundi L. calcarifer and various others, including mullets (Mugilidae), all of which are present either immediately below or within five kilometres of the dam wall (Thorburn et al. 2003; Doupé it al. 2005). The occurrence of four L. calcarifer above the Diversion Dam is likely the result of escapes from aquaculture in Lake Argyle (Doupé and Lymbery 1999) or by their release into Lake Kununurra by recreational anglers. The current debate regarding the development of Lake Kununurra as a barramundi fishery has raised the issue of the feasibility of building a fishway between Lake Kununurra and the lower Ord River, either directly at the Diversion Dam, or indirectly via Packsaddle Plain and the Dunham River (Doupé and Bird 1999; Doupé it al. 2005). If such a scheme was to proceed, then it is possible that movement of catadromous species into the lake will occur. This may lead to the fish community above the Diversion Dam returning to a more natural condition, i.e. one that more closely mirrors that which would have been present before the dam was constructed.

\section{ACKNOWLEDGEMENTS}

We are grateful for the financial assistance provided by the Lake Kununurra Fish Stock Enhancement Committee, the support of its members and the project management provided by Dick Pasfield. Mark and Gerry Allen, Steve McIntosh, Andrew Storey and Dean Thorburn provided unpublished data. Thanks to Ernest Pucci and 'Jingles' Brown for access to the Lake Argyle Spillway. We also appreciate the general cooperation and hospitality of the East Kimberley community, and in particular the general help and hospitality extended by Steve McIntosh and Sheree Lethbridge.

\section{REFERENCES}

Allen, G.R. (1975). A preliminary checklist of the freshwater fishes of the Prince Regent River Reserve north-west Kimberley, Western Australia. Wildlife Research Bulletin of Western Australia 3: 1-116.

Allen, G.R. and Burgess, W.E. (1990). A review of the 
glassfishes (Chandidae) of Australia and New Guinea. Records of the Western Australian Museum Supplement No. 34: 139-206.

Allen, G.R., Midgley, S.H. and Allen, M. (2002). Field Guide to the Freshwater Fishes of Australia. Western Australia Museum, Perth.

Beumer, J.P. (1979). Reproductive cycles of two Australian freshwater fishes: the spangled perch, Therapon unicolor Gunther, 1859 and the East Queensland rainbowfish, Nematocentris splendida Peters, 1866. Journal of Fish Biology 15: 111-134.

Bishop, K.A., Allen, S.A., Pollard, D.A. and Cook, M.G. (2001). Ecological studies on the freshwater fishes of the Alligator Rivers Region, Northern Territory: autecology. Supervising Scientist Report 145, Darwin.

Bunn S.E. and Arthington, A.H. (2002). Basic principles and ecological consequences of altered flow regimes for aquatic biodiversity. Ecological Management 30: 493-507.

Doupé, R.G. and Bird, C. (1999). Opportunities for enhancing the recreational fishery of Lake Kununurra using barramundi (Lates calcarifer): A review. Proceedings of the Royal Society of Queensland 108: 4148.

Doupé, R.G. and Lymbery, A.J. (1999). Escape of cultured barramundi Lates calcarifer (Bloch) into impoundments of the Ord River system, Western Australia. Journal of the Royal Society of Western Australia 82: 131-136.

Doupé, R.G., Morgan, D.L. and Gill, H.S. (2005). Prospects for a restorative fishery enhancement of Lake Kununurra: a high-level tropical impoundment on the Ord River Western Australia. Pacific Conservation Biology 11: 136-146.

Hutchins, J.B. (1977). The freshwater fish fauna of the Drysdale River National Park North Kimberley, Western Australia. Wildlife Research Bulletin of Western Australia 6: 1-133.

Hutchins, J.B. (1981). Freshwater fish fauna of the Mitchell Plateau Area, Kimberley, Western Australia. In, Biological Survey of Mitchell Plateau and Admiralty Gulf, Kimberley, Western Australia. Western Australian Museum, Perth.
Jaensch, R.P. (1993). Lake Kununurra. p.115. In S. Usback and R. James (eds) A Directory of Important Wetlands in Australia, 115. Australian Nature Conservation Agency, Canberra.

Llewellyn, L.C. (1973). Spawning, development, and temperature tolerance of the spangled perch, Madigania unicolor (Gunther), from inland waters in Australia. Australian Journal of Marine and Freshwater Research 24: 73-94.

MapInfo Corporation (1998). MapInfo professional-user's guide. MapInfo Corporation, New York.

Merrick, J.R., and Schmida, G.E. (1984). Australian Freshwater Fishes: Biology and Management. Griffin Press, Netley.

Morgan, D.L., Gill, H.S. and Potter, I.C. (1998). Distribution, identification and biology of freshwater fishes in south-western Australia. Records of the Western Australian Museum Supplement No. 56: 1-97.

Morgan, D.L., Allen, M.G., Bedford, P. and Horstman, M. (2004). Fish fauna of the Fitzroy River in the Kimberley region of Western Australia - including the Bunuba, Gooniyandi, Ngarinyin and Walmajarri Aboriginal names. Records of the Western Australian Museum 22: 147-161.

Morgan, D.L. and Gill, H.S. (2004). Fish fauna in inland waters of the Pilbara (Indian Ocean) Drainage Division of Western Australia - evidence for three subprovinces. Zootaxa 636: 1-43.

Thorburn, D.C., Peverell, S., Stevens, J.D., Last, P.R. and Rowland, A.J. (2003). Status of Freshwater and Estuarine Elasmobranchs in Northern Australia. Report to the Natural Heritage Trust.

Water and Rivers Commission (2000). Ord River Scientific Report. Recommendation for Estimation of Interim Ecological Water Requirements of the Ord River. June 2000. Water and Rivers Commission, Perth.

Manuscript received 14 November 2003; accepted 23 March 2005 